\title{
Employment preservation and textile regulation in early modern England, 1550-1640
}

\author{
John H. Gendron* \\ Department of History, Texas Tech University, Lubbock, TX, USA \\ ${ }^{\star}$ Corresponding author. Email: John.H.Gendron@ttu.edu
}

(Received 2 July 2020; revised 16 February 2021; accepted 18 February 2021; first published online 19 March 2021)

\begin{abstract}
Much agreement exists among economic historians that an institutional structure which allows for broad participation in a country's economy is conducive to growth. With respect to England's institutional structure, changes that followed the Glorious Revolution of 1688 are given pride of place in recent literature. This article contributes to this literature by highlighting and explaining regulatory change that removed barriers to entry into the country's most vital industry, textiles, in the years between 1550 and 1640 . However, although economic historians have tended to explain England's growth-facilitating institutions as arising abruptly through political revolution that placed constraints on the Crown, this article will elucidate change that was protracted, accretive, peaceful, and came through royal institutions. More specifically, this article argues that restrictive regulations, which were widely supported, were removed because Crown and Council, in consultation with local officials, recognized that enforcement would come at the cost of the greater priority of employment preservation.
\end{abstract}

Key words: N43 - Europe; pre-1913

\section{Introduction}

The spread of social institutions that enabled greater participation in economic activity and political life likely contributed to the broad-based economic growth of the 19th century. Ogilvie (2019), North et al. (2009), and Acemoglu and Robinson (2012) refer to these institutional arrangements as 'generalized', 'open-access', and 'inclusive', respectively. ${ }^{1}$ England's institutional structure has received much scholarly interest due to its precocious industrialization and growth in living standards. The Glorious Revolution of 1688 and, to a lesser extent, the English Civil War of the 1640s are given pride of place in trying to account for the country's institutional change that fostered growth.

North and Weingast (1989), for example, argued that the Glorious Revolution swung political power decidedly in favor of Parliament over the Crown thus securing greater governmental commitment to property rights, and that these changes were critical to England's development. Acemoglu and Robinson (2012) contended that 1688 was England's institutional 'turning point', while Acemoglu et al. (2005) saw 1688 along with the English Civil War as 'the two milestones in the emergence of political institutions constraining royal power' which were 'central to subsequent economic growth'. Similarly, Pincus and Robinson (2014) argued that the Glorious Revolution was an institutional watershed, in part, because it enabled 'party ministries [who] depend on public support...rather than the king [to] set the economic agenda', and 'property rights might have become a lot less secure' had this shift in power not occurred. Hodgson (2017) argued the Glorious Revolution 'triggered a series

\footnotetext{
${ }^{1}$ For subtle distinctions between these terms, see Ogilvie and Carus (2014: 428-429).

( ) Millennium Economics Ltd 2021. This is an Open Access article, distributed under the terms of the Creative Commons Attribution licence (http://creativecommons.org/licenses/by/4.0/), which permits unrestricted re-use, distribution, and reproduction in any medium, provided the original work is properly cited.
} 
of events that prepared the ground' for changes to financial institutions that enabled the country's economic 'take-off after 1760'. Lastly, Broadberry et al. (2015) noted, 'What was required [for growth] was both the growth of state capacity and the constraint of the executive, as occurred in....England as was doubly confirmed by the outcome of the Civil War of 1642-51 and the Glorious Revolution of 1688'. The conventional wisdom, then, is that the emergence of generalized institutions involved a sudden dramatic shift of political power and institutions that constrained royal authority. ${ }^{2}$

This article, on the other hand, will elucidate a set of institutions that became much more generalized prior to 1640 through a process that was protracted, accretive, peaceful, and operated through, rather than constrained, royal institutions. Specifically, this article will explain how England's most vital industry, textiles, was spared the imposition of highly 'particularlized' institutions (Ogilvie, 2019 ) - i.e. those which serve the interest of a particular group at the expense of others - between the years 1550-1640. Over these years, particularized regulations on wool middlemen, quality standards, industrial organization, and labor markets were abrogated, attenuated, or deliberately not enforced, and, as a result, barriers to entry were lowered, allowing industry to develop within a more generalized institutional framework. Despite having the backing of powerful interest groups, such restrictive regulations failed because the Crown and its Privy Council - who, before the Glorious Revolution, were the principal handlers of economic policy in general (Clay, 1984: 203) and textile regulation in particular (Keirn, 1992: 2) - in consultation with local elites serving as both royal officials as well as advocates of their localities (Goldie, 2001; Wrightson, 1980) recognized that strict enforcement of regulation would disemploy workers, which was deemed a worse outcome than the non-enforcement of otherwise desirable regulation. ${ }^{3}$ Put simply, unemployment posed a significant threat to the national government's 'simple mandate: to keep the peace and defend the realm against external and internal enemies' (Jones, 2011: 19).

Section 2 begins with a brief overview of which particularized institutions specifically had been removed, as well as a summary of the historiography on the subject.

Sections 3-5 will detail specific moments of generalized institutional change in the regulation of middlemen, quality standards, and corporate administration, respectively, revealing a near-century-long process in which discreet and seemingly minor changes, usually in the form of geographical exemptions to regulation, mounted over time.

Section 6 will conclude by explaining the importance of employment preservation to late-Tudor and early-Stuart regimes, and offer some concluding remarks.

\section{Regulatory change and its historiography}

The English textile industry witnessed a precipitous fall in cloth exports in the 1550s after an impressive run of good fortune that began in the 1480s (Brenner, 1993: 4-7; Fisher, 1940). The English government's response was characteristic of a regime committed to the ideal of a stable 'commonwealth' (Wrightson, 2000: 27) endeavoring to 'freeze society into a static mould' (Clay, 1984: 238). In 1551 parliament passed an 'Acte for the making of Wollen Clothe' (5 \& 6 Edward VI, c. 6) which painstakingly strove to provide statutory weights and measures for every type of cloth made in the country. In 1552, wool middlemen were barred by statute ( 5 \& 6 Edward VI, c. 7) and in 1555 an Act (2 \& 3 Philip and Mary, c. 11) was passed that attempted to stem the development of rural industry and also mandated a seven-year apprenticeship for weavers. These regulatory initiatives, however, failed to satisfactorily achieve their goals, and in the early decades of the 17th century novel policies were embraced which sought to devolve administrative powers onto localized corporate bodies operating within a broader network of national regulation. These efforts, too, proved ineffectual - the Company of the Merchants of the Staple held a monopoly over the country's wool trade for just three years (1617-1620), while lofty aspirations to bring the nation's cloth production under local

\footnotetext{
${ }^{2}$ There are, however, dissenters to this perspective who emphasize a more evolutionary view of institutional change;see, for example, Murrell (2017) and Ogilvie and Carus (2014).

${ }^{3}$ For a more in-depth overview of the offices of the national government, see Jones (2011:19-26).
} 
corporate supervision never materialized (though came close to implementation in the 1620s). Thus, by the outbreak of the English Civil War, the initiative to bring the wool trade and textile industry under a national system of regulation had failed. While various regulatory efforts persisted beyond 1640 (Cooper, 1970; Ramsay, 1946) these were entirely local in scope, and, therefore, '[m] ost of what effective regulation there was in the textile industry by the second half of the [17th] century was...in existence because of strictly local initiatives, and its enforcement was to all intents and purposes in local hands' (Clay, 1984: 249).

This, of course, is a long-familiar narrative. However, debate has not been settled over precisely why the English government's initiative to bring textile production under a national regulatory apparatus had failed by the mid-17th century. Broadly speaking, four distinct explanations have been adduced. First, Davies (1956: 252) and Supple (1959: 246) propounded the thesis that regulatory enforcement foundered on fears of creating unemployment, and it is on their original insights this article builds. Davies' work focuses on apprenticeship laws generally (not solely in relation to textiles) while Supple broached the subject in the final pages of a book that deals chiefly with 17th century economic crises. Although Clay (1984: 246-248) drew on these studies to make similar claims, no original work on the subject has been undertaken to flesh out their original insights. The present article aims to fill this historiographical space.

Second, Whig and Marxist historians had long argued that 'laissez-faire' policies were adopted in the wake of the Civil War that swept away earlier industrial regulation (Cunningham, 1885: 202-205; Hill, 1967: 135; Hill, 1980: 111; Lipson, 1931: 265, 313, 324; Perkins, 1969: 54-55, 149; Stone, 1980: 47; Wilson, 1965: 50, 56, 64, 269) - this was the predominant interpretation into the 1970s (Cooper, 1970). Third, historians conducting research specifically in textile production took exception with this traditional telling, arguing that no sharp turn towards laissez-faire followed the Civil War. They correctly pointed out that deregulation had taken place before the conflict, just as efforts to regulate (albeit localized efforts) persisted afterwards. Considering this, these authors favored an alternative explanation for the breakdown of regulation which rested on administrative and legislative failure (Appleby, 1978: 99-100; Cooper, 1970; Ramsay, 1942: 482-483; Ramsay, 1946; Thirsk, 1978: 117). This interpretation is consonant with the broader conclusion drawn by current economic historians that the insufficient state capacity of the early modern English state made it 'difficult to enforce harmful economic policies even when they were promulgated by Parliament or executed by the Crown' due to the 'absence of a paid local bureaucracy' (Ogilvie and Carus, 2014: 425).

With respect to pre-1640 textile regulation this interpretation unquestionably has much merit, though it fails to tell the complete story for several reasons. First, the fact that regulatory measures frequently became points of contention, as will be shown below, suggests a significant degree of enforcement. This was because the primary means by which economic penal statutes were enforced was through private 'informers' compensated either through successful prosecution in court or by 'compounding' with a defendant in, or even out of, court (Beresford, 1957; Davies, 1956; Clay, 1984: 237). Second, rarely did late-Tudor or early-Stuart governments simply abandon policy on the basis that it was not being satisfactorily enforced. Wrightson (1980), for example, elaborates a decades-long process whereby local officials were eventually brought to heel in enforcing central government regulatory directives, while England's Poor Law, which called for a national system of poor relief, reached its final form in 1598 and 1601 - though statutory precursors date as far back as 1536 (Slack, 1990:17-19) - yet even the most optimistic estimates claim that it had not achieved national implementation until the 1690s (Hindle, 2004: 256). Lastly, and relatedly, rather than being passive agents resigned to administrative failure, the government played a quite active role in reducing regulation (see below, sections 3-5). An accurate account of why national regulation was not implemented needs to incorporate positive factors to account for this activity rather than merely relying on a negative explanation of governmental failure or insufficient state capacity.

More recently, a fourth explanation links regulatory change in textiles to a broader cultural and intellectual shift among society's elites, sometimes referred to as an inchoate 'improvement' ethos. Historians have observed an attitudinal shift beginning in the late-16th century which increasingly 
admitted space for individualistic profit-seeking as a source of social-good (Slack, 2015: 53-90). Both Wrightson (2000: 250) and Slack (2015: 87) have seen regulatory change in textiles as a byproduct of this cultural movement. However, as will be demonstrated below, the extent to which both the wool trade and textile production were permitted to operate outside the ambit of regulation had far outstripped what prevailing opinion endorsed. This is not to deny that any change had occurred in the realm of political economy as it related to textiles. Rather, when specific moments of intentional attenuation are examined in the three main areas of regulation - middlemen, quality standards, and corporate oversight - evidence strongly suggests that the government's primary motivation had been to preserve employment, not promote 'improvement'.

\section{Wool middlemen}

The 1552 Act, which outlawed wool middlemen, came at the behest of the Merchants of the Staple, who held a monopoly on the export of wool and had seen their profits eroded as domestic manufactures retained increasing amounts of the raw material (Bowden, 1962: 155; State Papers Domestic, hereafter SP, 14/84 f. 56; Acts of the Privy Council, hereafter APC, 1616-1617: 180). The law stated that only members of the Staplers' Company and cloth producers could purchase wool from growers directly. Though originating with private interests, the Act was consonant with firmly held beliefs that middlemen unduly raised prices and vitiated quality by deceptively intermixing inferior wool. If strictly enforced, in addition to eliminating middlemen, this law would have effectively bankrupted all producers who possessed neither the wherewithal nor the time to travel to wool-growing districts; nor could they purchase in the large quantities that growers desired to sell. It was precisely on these grounds that a host of exemptions to the Act were granted before it was ultimately repealed in 1624 .

The first of such came in 1555 when Halifax and its surrounding parishes were awarded a statute exempting them from the 1552 Act because poor producers were not 'hable to kepe a Horse to carry Woolles, nor yet bye much Wooll at once'. Interestingly, middlemen were not permitted to sell 'to the riche and welthye' clothiers who, presumably, could afford to travel directly to growers for their wool ( 2 \& 3 Philip and Mary, c. 13). Similarly, in 1581, the Privy Council clarified a proclamation made by Elizabeth I against middlemen, stating it 'was not to impeache or restraine anie graunte for the buying of wolles... whereby the poor people were sett on worke'(APC 1580-1581: 48, 72), and in 1585 the Council ordered that the 'poor [middle]men be not hereafter molested' with litigation in the northern counties of Northumberland, Cumberland, and Westmoreland so that they, along with wool growers, 'may be attendant upon in the Counties to serve as they shalbe directed from the Lord Warden' of the Marches in defense of the border (British Library, hereafter BL, Additional MSS 34324, ff.8-10). In 1589, the city of Lincoln received a similar statute to that of Halifax 'for the releefe of the Citie' (SP 14/108 f.47; Bowden, 1962: 121).

In 1590, Randall Tenche, a clothier from Leeds whom 'the better sorte of clothiers...made choice of (APC 1590-1591: 163), wrote to the Council purportedly 'with the full consent of all other clothiers in the North Partes' asking that the 1552 statute be strictly enforced due to the 'corupt practise of a great nomber of broggers [i.e., middlemen]' (APC, 1590: 168). The Council initially obliged Tenche's request, but within a few months the Earl of Derby, who was lord lieutenant of Lancashire and Cheshire, asked that the territories under his lordship be exempted from the statute. ${ }^{4}$ After consulting with Attorney General John Popham, the Council agreed that 'inconvenience... would arryse by th'execution of that statute', and an exemption was granted to the two counties under his lieutenancy (APC, 1590: 370-1). In making its decision, the Council cited a letter written by two of the Earl's deputy lieutenants (who were also Lancashire justices of the peace) regarding 'informations' - i.e. litigation initiated by private parties in return for a portion of the penalties collected (Beresford, 1957) - exhibited in the Court of Exchequer against cloth-workers in the town of Rochdale. In this letter, the two men pleaded on behalf of 'the justices of that county' that 'yf the same statute were executed in this

\footnotetext{
${ }^{4}$ Unfortunately, this letter is not extant.
} 
countrie, where the poor clothier ys not able to go to the grower of the wooles, neyther the grower able to come hither, ther were thousandes of poore people utterlie undone' (MSS of Lord Kenyon: 595).

Similarly, in the 1590s, the Council halted legal proceedings against producers in Canterbury because 'divers poore people are sett on worke and the towne doth receave greate benefytt' (APC, 1598-1599: 646, 737), and Edward Coke, speaking in the 1621 Parliament about his tenure as attorney general (1594-1606), stated '[t]hat in Queen Elizabeth's tyme when Informacions were browght against Broggers...there ensued soe greate Complaint and clamor from the poore Clothiers That the Informacions were restrained'. He offered Devon as an example where there existed only 'Weavers who cannot provide their owne Woolls' (Notestein et al.,vol. 4, 1935: 150). ${ }^{5}$ Indeed, by 1613 it appears that official policy was to afford exemptions to the 1552 statute according to social status, as evidence by a grant made to East Anglian producers by the Privy Council because, in their words, 'these poore men...deserve no lesse favour then those of other places' (APC, 16131614: 8).

This would change, however, in 1615 when James I issued a draconian proclamation calling for strict enforcement of the 1552 statute (irrespective of earlier exemptions) due to 'great and intolerable abuses' of middlemen which caused 'high prices' and 'sundrie falsifications and corruptions in... woolls' (SP 14/187 f.97). James I's motivation had likely come from a combination of pressure from wealthy manufacturers (BL, Lansdowne MSS 152, fo.46) along with wanting to give Cockayne's Project - i.e. a monopoly granted to the Merchant Adventurers in the export of dyed cloth - an advantage in the wool market (Bowden, 1962: 165). Resultantly, in 1616 the number of cases brought to the Court of Exchequer skyrocketed by as much as $1200 \%$ (Beresford, 1957), causing the Privy Council to limit the proclamation to only four months following shearing season. Still, however, the Council recognized the needs of the 'poorer sorte of converters' of new draperies - lighter and cheaper varieties of cloth that were growing in popularity (Pilgrim, 1959) - and allowed licensed middlemen to service the 'great numbers of...converters... unable to goe abroad and fetch [wool] in forraine countries [i.e., counties]' (APC, 1615-1616: 623-625). One month later a similar grant was extended to the Cinque Ports to ensure the 'poorer sort' of new drapery producers were furnished with wools because they 'have no meanes to fetche the woolls out of the inland countryes' (APC,161516:670).

Ultimately, James I's proclamation proved too restrictive, and while the Council came to recognize that a 'third hand was requisite betwixt the woolgrower and clothiers' (APC, 1619-1620: 246-247) they were unwilling to leave the trade entirely open to 'loose and deceiptfull brougers of woll' (APC, 16161617: 159). Thus, in 1617 the Staplers'Company was given a monopoly over the country's wool trade for 'the enlarging of trade and the employment of poore people' (APC, 1619-1621: 207-208). Although the Staplers' monopoly will be treated in more detail below (section 5), it is important to note here that the company's lobbying campaign stressed that their services as middlemen provided employment to poor manufacturers precisely because concerns surrounding employment carried such weight in policy decisions. In one pamphlet, for example, the company impressed upon the Council that 'by indeavor of the wooll marchant many millions of poore are sett on woorke' (SP 14/80 f. 19). The author categorized 'four sorts of people' based on their relationship to the wool dealer. The first 'sort' was the 'rich clothier' who 'could well spare' middlemen. The second was the 'meaner clothier' who, collectively, set 'thousands on work' though 'seldom or never travels into the wool country' and therefore 'cannot miss the wool chapman, for if they do they must presently put off all their workfolk, and become servants to the rich clothier'. The third sort were those who buy 'little or no wool' themselves, but instead purchase yarn from independent spinners that 'are so many in number that more than half the cloths' made in the West Country are 'made by means of these yarn-makers and poor clothiers that depend weekly upon the wool chapman'. The fourth 'sort' were the 'thousands of poor people' producing 'the new drapery' along the country's east coast who obtained their wool from

\footnotetext{
${ }^{5}$ For other accounts of Coke's comments on this subject, see Notestein et al. (1935, vol. 5: 177) and Journal of the House of Commons (1802, vol. 1: 552).
} 
middlemen. Another letter to the Council built on this point, in which the Staplers argued that 'the common welth can not misse Buyinge and Selling of woolles', pointing out that the new draperies 'kept as many on work as all the clothing in the lande' and that ' $\mathrm{t}]$ hese people must all want work if the marchante of the Staple or woolbuyer be taken from them' (SP 14/80 f.21). A third letter averred that 'the poore Clothier and artificer hath been furnished with woolls' by middlemen 'whereby many thousands of the kings subjects are sett on worke', and that the company's 'restraint is desired but for the profit of a fewe rich Clothiers' (SP 14/84 f.56).

While these arguments resonated with Crown and Council, the Staplers' monopoly was ultimately revoked after just three years on grounds that it had produced the opposite of its intended effect (see below, section 5), and a 'bill for free buying and selling of wool' was promptly debated in the 1621 Parliament. These debates took place amid falling wool prices which were, admittedly, an important factor in garnering support for the bill - it was widely agreed that wool should be kept at a 'reasonable price' to prevent reductions of bullion inflows (see below, section 5). Nevertheless, heated debate existed on whether to include a period of 'pre-emption' that would afford (wealthy) clothiers alone a privileged purchasing period following shearing season. Those opposed to pre-emption appealed to broadly shared sentiments on the importance of employing the 'poorer-sorte' of producer who relied on the service of middlemen. Guy Palmes, for example, expressed a common refrain among MPs in stating, '[i]f there were any preemption, the Clothiers buying that are rich may keep wool to dear, and also they that are rich would undoe the poore Clothiers' (Notestein, et al.,vol. 5, 1935: 177). ${ }^{6}$ The 1552 statute against middlemen survived the 1621 Parliament due only to its early suspension and was formally repealed in 1624 .

\section{Quality standards}

Ensuring high-quality standards in cloth production was, of course, closely related to other regulatory policies. As we have seen, restrictions on wool middlemen were partly justified by concerns to maintain quality in finished goods, and, as we will see in the next section, placing industry under localized corporate administration gained support largely for the same reason. This section, however, will focus more narrowly on efforts to enforce national statutory requirements more directly related to quality standards as well as the closely related seven-year apprenticeship mandate. Between 1552 and 1624 no less than 13 statutes were passed related to product standardization (Ramsay, 1946: 94) while apprenticeship requirements found statutory backing in 1555 (2 \& 3 Philip and Mary, c. 11) and 1563 (5 Elizabeth I, c. 4). Nevertheless, complaints of poor enforcement persisted throughout the period, and, while the mercantile community figured most prominently in these remonstrations, cloth producers themselves were frequently involved in these campaigns as well (Barford, 1924; Clay, 1984: 248; Cooper, 1970: 77, 82-83; Pilgrim, 1959: 55-56; Ramsay, 1965: 87-98; Sixta, 1953: 112114; Thirsk, 1978: 117). Royal cloth inspector John Leake's 1577 remark that 'better lawes in these points cannot be made, only ther wantes execucion' (quoted in Tawney and Power, 1924: 220) were quite representative of the pre-1640 attitude. Although some writers in the 1620s began expressing the idea that cheap, rather than 'dear', prices in cloth would work to England's competitive advantage in foreign markets (Supple, 1959: 221-223), the notion that all cloth should be subject to rigorous inspection according to statutory quality standards was a first principle of industrial policy throughout the late-Tudor and early-Stuart period (Clay, 1984: 248; Supple, 1959: 246-247; Thirsk, 1978: 116).

It was only late in the 17th century, it seems, that writers like Josiah Child were voicing the opinion that standardization laws 'do more hurt than good, because the Humors and Fashions of the World change, and at sometimes in some places (as now in most) slight, cheap, light cloath will sell more plentifully' (1698: 148) - or like Carew Reynell who desired an 'allowance for ingenious persons to set up themselves without being Apprenticed' $(1674: 19,49)$. There appears to be no evidence, however, that these views were present in the pre-1640 mindset with respect to textile production.

\footnotetext{
${ }^{6}$ For similar statements, see Notestein et al. (1935, vol. 2: 216, 381; vol. 3: 289; vol. 7: 574) and Journal of the House of Commons (1802, vol. 1: 552, 624).
} 
Despite this consensus, Crown, Council, and local administrators were hesitant to enforce quality standards when they threatened the livelihood of workers. In fact, when Supple (1959: 246) argued that the failure of mid-16th century textile regulation was due to the 'prevailing fear...of unemployment', he pointed to the regulation of quality standards and apprenticeship specifically to support his position. In addition to citing Davies' (1956) work on apprenticeship, Supple (1956: 146, 246-247) adduced the affairs of a 1630s 'Commission for Reformacion of the abuses in Cloth makeing' in the West Country (APC, 1630-1631: 94) which was rendered ineffectual in the face of local resistance. This had been a fairly well-known episode to textile historians (Barford, 1924; Ponting, 1971: 34; Ramsay, 1965: 87-98), in which the commission, backed by Merchant Adventurers and wealthy producers of white broadcloth, targeted the use of gig-mills - i.e. a device used to raise the nap on cloth (Barford, 1924: 534) that had been prohibited by statute (5 \& 6 Edward VI, c. 22) - as well as capitalist yarn-makers, known as 'market-spinners', who were outbidding the clothiers in labor markets and also providing yarn to their smaller competitors. Despite the commission's findings, the central government permitted the use of gig-mills (though proscribed future construction) as well as the activities of market-spinners due to warnings they received from the counties. Justices of the peace cautioned the Privy Council that the commission's wishes would 'reduce the trade of clothing into a narrower compass, and not employ so many poor; all clothiers that want great stocks of money will be beaten from their trade' (Calendar of State Papers Domestic, hereafter CSPD, 1633-1634: 249). Producers similarly warned that it would be 'the utter undoing of many thousands of poor people' (CSPD, 1633-1634: 165). In 1632, 'oppositions and combinations....against the commission' (CSPD, 16311633: 326) reached a fever pitch, and the commission's leader had even worried of a 'conspiracy to bring about his death' (CSPD, 1633-1634: 136-137). In his own words, he had been 'cast into the River of Avon where the place was twenty foote deepe and nine clothes then in the water, under any of which if I had risen I had been inevitably drowned' (quoted in Barford, 1924: 539).

Although this may be the best-known example of the government prioritizing employment and stability above the enforcement of quality standards, it is far from the only instance. In 1589-1590, the Privy Council decided against a proposal that would have vested the power to sue violators of quality standards in one man and his deputies. Tellingly, the arguments against the patent were rooted in notions of 'Common wealth', which at the time 'meant both the common good... and the social and political structures responsible for achieving that condition of public welfare' (Wrightson, 2000: 27), as well as the need for flexibility in order to ensure stability. It was pointed out, for instance, that inspectors in London employed discretion in enforcing quality standards 'for feare of a Common disturbance thoronghe England and the whole Citie', and that recently 'the Counsaile board were fayne [i.e., forced]' to stop 'informacons against clothiers in to the'xchequer' for similar reasons. It was further argued that 'theare was never [a] suite...to bee better advised on by the Counsaile board for Common quiet and trew benefit of the Common wealth', and warned against placing 'all tolleracion of faulte in clothinge to one mans hand' (BL Lansdowne MSS 60, f.21).

Such decisions were almost always made after consulting with local royal officials who, like the Crown and members of the Privy Council, prioritized employment and stability as advocates of their localities. In 1602, for example, when a complaint was brought before local justices of the peace in Essex against a fustian maker, it was dismissed because the trade 'appeared to the Court to be much profitable for setting the poor on work, and doubtful if [it] were any offense against the statute' (quoted in Davies, 1956: 227). In 1627, producers in West Riding were granted an exemption to a 1551 statutory ban on the use of 'hot presses' (5\&6 Edward VI, c. 6) only after local magistrates endorsed the decision. Upon receiving a petition from aggrieved clothiers being sued under the 1551 statute, the Council referred the matter to the local justices (APC, 1627-1628: 206-207, 307). After surveying their district, the justices indicated 'generall acclamacon and concurrence' on the benefits of the hot press, adding that the devices 'have bene very muche in use from the time of the making of the Lawes against them' and 'by occasion hereof Multitudes of families are sett on worke and manteyned which if the same shoulde be taken away should be left without Imployment or meanes' (SP 16/90 f.74). Similarly, in 1631, the Council received a petition from Suffolk justices of the peace 
recommending that an earlier 1608 'Toleracon' for stretching cloth beyond statutory limits be reaffirmed (SP 16/240 f.56). Producers in and around the town of Hadleigh were being sued, prompting the justices to warn that 'the sustenance of the poore people should be molested and troubled by Informers and soe Discurages [them] to goe on in their trade'. They explained that the 'Toleracon' granted by the Council under James I had brought 'not hurt but profit to the Comon Wealth' and therefore should be upheld (SP 16/192 f.37). Ultimately, the Council agreed, stating that if the clothiers were prosecuted it 'would breed a great disturbance in that trade and manie inconveniences would thereupon insue' (APC 1630-1631:342).

Crown and Council also consulted local officials in formulating policies to regulate the new draperies, which were introduced by Dutch settlers in the late-16th century (Coleman, 1969) and grew prodigiously through the 17th century (Muldrew, 2012: 502). Initially, the new products escaped scrutiny because their production took place under strict corporate supervision in urban settings such as Colchester, Norwich, Sandwich, and Halstead - in fact, contemporaries often held these companies as paragons of inspection whose institutions should be replicated elsewhere (May, 1613: 6-7; Misselden, 1622: 128; Notestein et al., vol. 7, 1935: 201; Ramsay, 1942: 491). However, the new products began to 'spread out gradually' (Wrightson, 2000: 166) into 'country areas... where...regulation was almost nonexistent' (Pilgrim, 1959: 45), and by the second decade of the 17th century urban producers were clamoring for tighter regulations on the industry as a whole. In 1618, these producers were asking that 'intruders...be suppressed...unles they have bene apprentice[d] therto by the terme of 7 years', and 'That all such good Actes that are made' for traditional woollens should 'stande in effect for the...new drapery' (SP 14/104 f.155). These concerns were again reiterated in a second letter (BL Additional MSS 39245 f.59) after the short-lived 1621 Parliament failed to vote on a bill 'to reduce all the New-Draperie to the old perfeccion and goodnes' (Notestein et al., vol. 4, 1935: 216). Shortly thereafter, the Council asked local justices of the peace to determine whether the complaints surrounding 'intruders' and 'insufficiently made' goods were 'grounded upon just causes', and, if so, 'what course wilbe most expedient' (APC, 1621-1623: 156). The justices of both Suffolk and Essex concurred that the complaints were legitimate, though neither could recommend a practical remedy. The Suffolk justices warned it would be 'dangerous to suppress those unapprenticed...being two-thirds of the whole, as many poor would thus be thrown out of work' (CSPD, 1619-1623: 379), while the Essex justices noted that 'the makers of...new drapery, doe hould themselves free to use and exercise the making... of them, albeit they never served as apprentices...And doe also hould themselves not to bee within the intent of any statute heretofore made for the making ordering and dressing of woolen cloath'. Unsure how to proceed, the Essex justices put the onus back on the Council, stating, '...if Your Lordshipps conceive that the lawes heretofore made...will not reach this newe drapery wee thinke the remedie for the present must bee by some authority derived from his Majestie and Your Lordshipps...' (SP 14/130 f.83). Despite the urban producers' request that a 'Proclamation may come forth for the easing of their grievance' (SP 14/104 f.155), the Council chose not to interfere.

The final nation-wide standardization statute was passed in 1625 (21 James I, c. 18) - though the flourishing new draperies and West Country 'Spanish cloth' were conspicuously absent (Ramsay, 1946: 94-95) - and by 1640, the government's near-century long effort to impose national standards on cloth had failed, never to be revived again. Tacit acknowledgement of this shortcoming is apparent in the 1640 report of the Royal Commission on the Clothing Industry, formed in 1638 to investigate the 'causes of the decaye of the vent' of cloth (Ramsay, 1642: 485). Unlike its 1622 predecessor, which had implored parliament to pass 'one Clere Lawe' for both old and new draperies in order to redress 'false and deceitfull makeinge...of Clothes' (quoted in Ramsay, 1965; 148), the 1640 Commission made no mention of the need for future standardization statutes. Instead, it suggested that certain local corporations should set their own ordinances to be 'observe[d] without alteration, unlesse the same bee allowed by the [corporation's] Commissioners' (quoted in Ramsay, 1642: 492). How do we account for this pivot away from such long-standing precedent? The Commission was actually quite explicit in providing the persistent abuses that had led to their recommendations (Ibid.: 486487). Tellingly, six of the nine stubborn 'deceipts' complained of by the Commission had, as we 
have seen in the forgoing discussion, already been permitted on the basis of preserving employment: 'great abuse[s]' from the use of 'gigmills' in the West Country; middlemen's 'mixing of diverse sorts of Woolls'; the 'abuse of...Market Spinners'; 'Workmen that have not served their Apprentishipe'; 'Excessive streyninge and stretching' (in particular, 'the Tolleracion...in Anno 1608'); and the negligence of local 'Sealers of Cloth' who were typically appointed by justices of the peace (Heaton, 1920: 178) and were thus more concerned with local tranquility. ${ }^{7}$ It was the persistence of these 'diverse and manifold abuses' which led the Commission to exasperatingly conclude, 'there can bee noe other waye for an absolute and generall Reformacion, but by the grauntinge of several Incorporacions to all the chiefe Clothing Townes', with jurisdiction over their rural surroundings. Although this ambitious scheme never came to fruition, its localized approach to the regulation of quality standards would characterize policy for the remainder of the 17th century (Clay, 1984: 249).

\section{Corporate administration}

Considerations to administer both the domestic wool trade and woollen cloth industry through localized corporations operating within a nationally-integrated system began to be taken seriously in the early decades of the 17th century. Between 1617 and 1620, the Staplers' Company was granted a monopoly over the wool trade with full administrative authority within 'staple towns', and in 1625 royal charters were drawn up for the creation of 32 county-wide cloth corporations which never materialized and were never seriously considered again. This section will examine these initiatives, explaining their underlying logic as well as the reasons each were abandoned.

Grounds for placing the wool trade under the auspices of the Staplers' Company in 1617 were due to the recent recognition that 'a third hand was requisite betwixt the woolgrower' and producer ( $A P C$, 1619-1621: 246-7) and because the Staplers possessed 'government and experience' to reform 'abuses in waights and undue mixtures' of wool - as opposed to 'the loose and deceiptful brougers of woll' who possessed no such 'authority or government' (Ibid.: 158-159). The company's monopoly, however, would last just three years. Bowden (1962: 173-174), in his authoritative study on the wool trade, argued that the Staplers' patent was revoked mainly to reverse the fall in wool prices by admitting more buyers. While partly correct, this explanation does not go far enough. The government's concern to raise the price of wool was understood as a means to remedying a depression in the economy in general and the cloth trade in particular. Crown, Council, and Parliament agreed that a fall in wool prices effected a fall in cloth prices which contributed to the unbalancing of trade and a shortage of bullion. It was for this reason that parliament's 'Committee on the Scarcity of Coin' listed both the Staplers' patent and the low price of wool as exacerbating bullion shortages (Nicholas, 1766, vol. 1: 151; Notestein, et al., vol. 4, 1935: 150; Ibid., vol. 6: 59). Money was understood as a necessary lubricant to the gears of the economy. As Sir Edwin Sandys explained, without coin 'the Farmour is not able to pay his rent', the 'Fayres and Marketts stand still', and 'loomes are layde downe' as the poor are forced 'to seeke another inheritance'. Sandys further warned, 'Bellum Rusticorum in Germany proceeded from this, That the poore wanted worke' (Ibid., vol. 4: 104).

However, perhaps more important than falling wool price in turning official opinion against the Staplers' monopoly was the threat posed to small-scale manufacturers and undersized middlemen. In fact, well before concerns were first voiced in the Council over falling wool prices in September 1620 (SP 14/116 f.152), complaints had already come forth from all over the country on the disenfranchising effects of the Staplers' patent. In 1618, the 'Inhabitants' of Cumberland, Westmoreland, and Northumberland petitioned the Council for an allowance to 'sell their woolles as usually they have done' because the Staplers were not buying their wool. They explained that 'many thousande of the woolgrowers of those 3 Counties' did not have the 'meanes to bring their woolles' to the company's

\footnotetext{
${ }^{7}$ Regarding the negligence of local administrators, this article's thesis is consonant with one royal inspector's observation that 'The Magistrates...perceavinge what multitudes of poore do hange uppon them, have muche favoured the matter, that thereby all the falshoodes [in cloth making]...hath bene covered as it were under a bushell'(Tawney and Power, vol. 3, 1924: 220-221).
} 
designated staple towns, and that the middlemen who had traditionally purchased the counties' wool were 'very poore men' who would 'rather choose to give over their trade then to become Staplers, by paying a fine to be admitted [into the Company], the woolles beinge soe Course as their gaine is very small' (BL Additional MSS 34324 f.14). A leading gentleman of Cumberland reiterated these points in a letter to Lord Zouche of the Privy Council in 1619, explaining that 'experience hath taught howe inconvenent it would be to those partes, especially the poorer sort, yf our wool men ther weare barred from buying our Countrie woolls' (SP 14/109 f.86). Similarly, a petition of Warwickshire middlemen, undersigned by 101 'broggers' and small clothworkers, warned that they would be 'utterly undone' and that the 'poor clothiers are like to perish' if the Staplers' monopoly persisted. The petitioners explained that the poor clothworkers 'cannot repair to the staple towns without more expense than their gains can countervail' and that the Staplers would not 'sell the like small quantities' that they could afford. Additionally, it was alleged that the Staplers 'enforce[d] your petitioners either to give great sums of money to be of their company or by continual arresting of them compel them to be bound not to deal for wools' (Thirsk and Cooper, 1972: 203). Likewise, in 1619 the Mayor of Lincoln wrote to the Council asking that the Staplers' entrance fees 'be at some reasonable rate...according to the abilitie of the poore citizens' of the city. The mayor explained that the company's fee was 'at such a rate as is farr above the abilitie of any citizen', and that without middlemen ' 3 or 400 poore people who now are ymployed' by 'converting wooles into yarne and other manufactures' would 'fall into idleness and begging...for that the Citie shall not be able to fynde any other meanes to set such a multitude of poore on worke as now they do by that meanes' (SP 14/108 f.47). Lastly, in 1620, Lord Spencer of Northamptonshire and the justices of the peace of four counties expressed identical complaints to the Council. The Staplers, they argued, 'have taken into their companies many of the best broggers... and caused informations to bee exhibited against the meanest broggers, ether to forse them to become staplors or utterly suppresse them, whereby...the woollgrowers as [well as] the meanest sorte of cloathers are deprived of one sorte of chapmen' (APC, 1619-1621: 207-208). To reiterate, each of these complaints were made prior to the Council expressing concern over a fall in wool prices.

The 1621 Parliament continued this line of attack, with MPs claiming the company used its privileged position to suppress competition. Just a brief sampling of the many complaints levied against the Staplers' monopoly include: 'none could be admitted into the...Staplers under 111l.' (Notestein, et al., vol. 5, 1935: 468); 'men were restrained from buying' and therefore not 'enough [buyers] to buy the Fortieth part of Woolls of this Kingdom' (Ibid., 457-8); 'that there was 180 Looms laid down in Worcester within 6 months' because of the Staplers' restrictions, while 'Barnstable had 400 loomes, now not a 100' (Ibid., 486, 506); producers in Kent claimed that 'one...cause they make no more Cloth is, that they are restrained from buying of Wool' (Nicholas, 1766, vol. 1: 87); that the patent went against 'Queen Elizabeth finding the [1552] Statute [which the Staplers were enforcing]...to be prejudicial to the Common Wealth...forbid[ing], that any Informations should be exhibited upon that Law' (Notestein, et al., vol. 5, 1935: 487); 'Much Wool' was being 'engrost by Rich men' (Ibid., vol. 4: 97); 'divers Broggers had been by Information...compelled either to compound [with the Staplers] or to give over buying and selling of Wools' (Ibid., vol. 5: 486); and that the 1552 statute 'was never held but as a Snare' by 'those Staplers who procured it' (Nicholas, 1766, vol. 2: 105).

It thus seems very likely that even in the absence of falling wool prices - which itself was understood by contemporaries to be the upshot of restrictions on competition - the Staplers' monopoly would not have survived. Near-unanimity existed among MPs that the Staplers had used their privileged position to exclude and suppress their undersized competitors and that this had, in-turn, left producers who relied on their services particularly vulnerable. This situation was simply unacceptable to a parliament that prioritized 'the need to maintain social order' when formulating economic legislation and was sitting amid a deepening depression in the cloth trade (Pennington, 2006: 227-229). This interpretation is further supported by James I's proclamation on July 10, 1621 to remedy the 'publique greevances' of the recently dissolved parliament, in which the Staplers' patent was included 
in a list of annulled grants deemed to be 'grievances... upon many of his people, and chiefly the poorer sort' (Steele, 1910: 155). ${ }^{8}$

Regarding the reason for the English government's inability to bring cloth production under localized corporate administration, we are unfortunately forced to draw conclusions from a relative paucity of source material. This initiative came closest to implementation in 1625, when charters for 32 county-wide cloth corporations were drawn-up though never executed. Historians have correctly concluded that this 1625 scheme was abandoned because of the more urgent demands of foreign affairs (Cooper, 1970: 84; Fisher, 1933: 193; Heaton, 1920: 219). This, however, does not explain why similar proposals were never seriously considered again. Zell (2001: 673) has argued that 'even without the wars of the late 1620 s...the project would probably have been stillborn, for there is no evidence of any local interest or support'. Evidence, however, suggests otherwise: in 1618 (SP 14/104 f.155) and 1621 (BL Additional MSS 39245 f.59) urban new drapery producers of East Anglia called for local corporations to oversee compliance with apprenticeship laws and quality standards; in 1621 and 1624 bills were introduced at the urging of Exeter's officials calling for what amounted to corporate oversight in 'anie Cittie or market Towne' where certain new draperies were sold (Cooper, 1970: 82-83; Notestein et al., vol. 7, 1935: 197-202); Leeds was incorporated in 1626 at the behest of 'the wealthier clothiers and merchants of the parish' primarily for the purpose of enforcing quality standards (Heaton, 1920: 221); in 1634 Exeter again 'sought powers to regulate the manufacture of perpetuanas...presumably outside their walls', and in 1636 the city's combers were incorporated (Stephens, 1958: 53-55); the 1638-1640 Royal Commission on Cloth recommended corporations in every clothing town only after 'diverse [clothiers]...declared their approbacion' (quoted in Ramsay, 1942: 491); and during the Interregnum, members of the clothing communities of Norwich, Exeter, Taunton, and Leeds lobbied for cloth corporations to be established in their respective locales (Ramsay, 1946). Corporate oversight, thus, appears to have had significant support in certain locations.

Perhaps a better explanation for the long-term failure of cloth corporations on a national-scale was offered by Fisher (1933), who pointed out that despite being endorsed in principle the corporations were ultimately abandoned because they 'could not function in fields where competition and the clash of conflicting interests were sweeping away the foundations upon which self-government had to be built' (Fisher, 1933: 193-194). Indeed, as we have seen, the justification for cloth corporations was founded on the belief that they could effectively enforce the very regulations that had already been shown to threaten employment. It is unlikely that the difficulties accompanying national implementation of such a scheme would have been lost on Crown and Council. Although the source material is surprisingly scant on this topic, it is possible to glean this recognition in the 1640 report of the Royal Commission on Cloth. Regarding the creation of urban-based cloth corporations, the commissioners indicated:

...we beleeve [corporations] wilbe most willingly embraced, by all the Clothiers of this Kingdom, diverse of them havinge already declared their approbacion thereof, But by reason wee were uncertaine howe this Waye would bee accepted of, wee thought it not expedient to spend much time in entringe too farr in the perticulers, untill wee should receive your Majesties further Commands and direccons.

Whether the 'reason' for not delving into 'the perticulers' was uncertainty about the king's reception or that of unconsulted clothmakers (or both) is debatable. However, the fact that the commission could not confidently recommend a national network of corporations is an indication that attitudes had shifted since 1625 . As to what had triggered this change there is still room for historiographical debate.

\footnotetext{
${ }^{8}$ In addition to revoking the patent for the 'brogging of wool', James I's proclamation - which was issued because the short-lived 1621 Parliament was not 'able in the time of sitting to settle all grievances' - also annulled such royal grants as the 'sole making of tobacco pipes, the hotte presse, [and] the manufacture of playing cardes'. Such concerns over the anti-competitive effects of royal policy would ultimately culminate with the passing of the Statute of Monopolies in 1624.
} 
Perhaps central governors were given a glimpse of the disruptive effects of cloth corporations after bitter disputes erupted in both Leeds in 1626 (Heaton, 1920: 220-242) and Exeter in 1636 (Stephens, 1958: 54-55) following the formation of chartered craft corporations. In both cases, small independent extra-urban producers vehemently opposed the imposition of corporate regulations by their urban counterparts. Admittedly, this an argument from silence, but considering the dearth of source material it is not unreasonable to conclude that governors had given up on the idea of erecting cloth corporations throughout the country because they foresaw the resentment that such a heavy-handed measure would elicit.

\section{Conclusion}

The evidence presented in this article strongly suggests that the imposition of a national system of regulation on the wool trade and textile industry had failed because Crown and Council, in consultation with local elites serving as both royal officials as well as advocates of their localities, recognized that such a system could only be achieved at the expense of the more important goal of maintaining employment. The reason employment held such purchase in the minds of the governing classes was because it was closely woven with so many other areas of concern. While the successive regimes of late-Tudor and early-Stuart England certainly faced unique challenges, all operated within an environment of unusually high anxiety and insecurity. Historians frequently characterize England at this time as a "Beleaguered Isle', a small and worried nation...nervously calculating the chances of its regime's survival in the face of internal and external enemies' (Sharpe, 1995: 205; Wiener, 1971). Internally, religious disputes, recurring harvest failures and grain riots, uncertainty surrounding Elizabeth I's succession, growing concern over 'visible poverty' (Wrightson, 2000: 149) resulting from long-term socio-economic change (Coleman, 1956; Sharpe, 1995), coupled with the widely held belief that clothworkers were, in the words of Lord Burghley, 'of worss condition to be quyetly governed than the husband men' (Tawney and Power, vol. 2, 1924: 45) contributed to the government's conspicuous concern to maintain employment in textiles. Domestic anxieties had also contributed to the passing of a series of Poor Laws in the second half of the 16th century (Hindle, 2000: 146147), the financing of which placed added pressure on justices of the peace (Slack, 1990: 19, 28) to preserve employment. Externally, foreign invasion became an appreciable threat in 1584 (Hammer, 2003: 116-117), and the need to maintain employment in order to shore-up defenses was an expressed motive behind exemptions granted to middlemen in the northern border counties in 1585 (BL Additional MSS 34324, ff.8-10) and in towns near the Cinque Ports in 1616 (APC,1615-1616: 670).

Perhaps just as important to this process was the still-powerful medieval concept of 'commonwealth', which, in theory, 'signified the idealization of an organic society with a managed economy in which subordinates were looked after in exchange for deference' (Muldrew, 2013: 320). While this prescriptive ideal of society as 'organic' and static was losing much of its force amid changes ushered in by a burgeoning market economy (Wrightson, 2000: 202-203), its spirit of 'paternalism' persisted, growing 'particularly strong in the second half of the 16th century' as it became 'less concerned with the reconstruction of a decayed idyll than with the preclusion of present and future disorder' (Hindle, 2000: 147-148). As we have seen, the term 'commonwealth' and its foundational commitment to the 'corporate responsibility of society for the welfare of its members' (Jones, 2000: 15) were salient features of the language used to justify the regulatory changes highlighted in this article.

This interpretation offers additional nuance to the current historiography on similar marketoriented policies that reduced regulation in other areas of the economy. This literature - for example, on domestic grain markets (Slack, 2017), agrarian enclosures (McRae, 1996: 7, 76; Slack, 2017: 68), usury (Jones, 1989: 174; Jones, 1992: 176-177, 195-196; Slack, 2017: 67), privileged trading companies (Pennington, 2006), as well as textiles (Slack, 2015: 87; Wrightson, 2000: 250) - emphasizes the emergence of novel attitudes, sometimes called an 'improvement' ethos (Slack, 2015), that increasingly approved of profit-seeking and the market in general. However, as this article has shown, the degree to which textile production operated free of regulation had far outstripped what prevailing opinion 
condoned. Thus, while it is entirely possible, and indeed likely, that novel attitudes towards the market helped consolidate and sustain the regulatory changes that are the focus of this article, they were not the mainspring of that change.

Lastly, one could reasonably counter this article's central thesis by pointing out that both opponents and proponents of regulation invoked employment to justify their position. While it is correct that proponents did appeal to employment security in support of regulation, experience often ran counter to these claims. For example, while the Staplers' Company's 1617 monopoly was instituted 'for the enlarging of trade and the imployment of poore people' (APC, 1619-1621:207) three years of experience revealed it to be 'contrary to the good intent of the...proclamation' (Ibid.: 247). Additionally, the two sides frequently argued from very different positions, which could materially affect policy decisions. On the one hand, supporters of regulation usually spoke of the need to remedy a general condition for which there was no immdediate solution - for example, the 'great decay of the Trade of Clothes' (Ramsay, 1942: 485) - whereas campaigns to reduce or remove regulation, as we have seen, were usually successful when specific enforcement efforts threatened the livelihood of workers and could be remedied immediately.

In order for the English government to uphold regulation amid competing calls for employmentsecurity, the threat posed by regulation must have been seen as comparatively insignificant. This can be illustrated in a dispute between East Anglian country spinners and Norwich officials over quality standards that the latter had imposed on yarn sold within the city. The matter was brought before the Privy Council who investigated the dispute in earnest because, in their words, 'both...Peticions...concerne the lyvelyhood and maintenance of many thousands of people and many families' (APC, 16291630: 221). After initially siding with the country spinners - 'to the end [that] poore people may bee the better comforted in their Trades and vocations' (Ibid.: 125) - the Council ultimately upheld the city's ordinance after a second hearing. The reasoning for this reversal is quite revealing. Additional evidence demonstrated that enforcement of the ordinance had been soe moderate and spareing as that in twelve years past the valewe of the goods seized amounted not in all to above fower score pounds'. In light of this discovery, the spinners' complaint appeared 'rather clamorous then just' (Ibid.: 276). It was thus possible for controversial regulation to be upheld so long as the social cost of enforcement was perceived to be less than that of non-enforcement. However, as this article has argued, the government's internal calculations more often moved policy in the opposite direction. Regulations on the production of textiles became more generalized over time precisely because the English government saw enforcement as the greater threat to the country's social fabric.

Acknowledgements. I would like to thank Abigail Swingen and Stefano D'Amico for their many helpful discussions, as well as the three anonymous referees for their insightful, careful, and conscientious comments and suggestions. I would also like to express my gratitude to the Rachel E. Hudson European Studies Scholarship which made this research possible.

\section{References}

Acemoglu, D. and J. A. Robinson (2012), Why Nations Fail, New York: Random House.

Acemoglu, D., S. Johnson and J. A. Robinson (2005), 'The Rise of Europe: Atlantic Trade, Institutional Change and Economic Growth', American Economic Review, 95(3): 546-579.

Appleby, J. (1978), Economic Thought and Ideology in Seventeenth Century England, Princeton: Princeton University Press.

Barford, K. E. (1924), 'The West of England Cloth Industry: A Seventeenth Century Experiment in State Control', The Wiltshire Archaeological and Natural History Magazine, 141(42): 531-542.

Beresford, M. W. (1957), 'The Common Informer, the Penal Statutes and Economic Regulation', Economic History Review, 10 (2): 221-238.

Bowden, P. (1962), The Wool Trade in Tudor and Stuart England, London: Palgrave Macmillan.

Brenner, R. (1993), Merchants and Revolution, Princeton: Princeton University Press.

Broadberry, S. N., B. Campbell, A. Klein, M. Overton and B. Leeuwen (2015), British Economic Growth, 1270-1870, Cambridge: Cambridge University Press.

Clay, H. (1984), Economic Expansion and Social Change: England, 1500-1700, vol. 2, Cambridge: Cambridge University Press.

Coleman, D. C. (1956), 'Labour in the English Economy of the Seventeenth Century', Economic History Review, 8(3): $280-295$. 
Coleman, D. C. (1969), 'An Innovation and its Diffusion: The "New Draperies"', Transactions of the Royal Historical Society, 22(3): 73-99.

Cooper, J. P. (1970), 'Economic Regulation and the Cloth Industry in Seventeenth-Century England', Transactions of the Royal Historical Society, 20(1): 73-99.

Cunningham, W. (1885), The Growth of English Industry and Commerce in Modern Times, Cambridge: Cambridge University Press.

Davies, M. (1956), The Enforcement of English Apprenticeship, a Study in Applied Mercantilism, 1563-1642, Cambridge: Harvard University Press.

Fisher, F. J. (1933), 'Some Experiments in Company Organization in the Early Seventeenth Century', Economic History Review, 4(2): 177-194.

Fisher, F. J. (1940), 'Commercial Trends and Policy in Sixteenth-Century England', Economic History Review, 10(2): 95-117.

Goldie, M. (2001), 'The Unacknowledged Republic: Officeholding in Early Modern England', in T. Harris (ed.), The Politics of the Excluded, c. 1500-1850, New York: Palgrave, pp. 153-194.

Hammer, P. E. (2003), Elizabeth's Wars: War, Government and Society in Tudor England, 1544-1604, New York: Palgrave Macmillan.

Heaton, H. (1920), The Yorkshire Woollen and Worsted Industries, From the Earliest Times up to the Industrial Revolution, Oxford: Oxford University Press.

Hill, C. (1967), Reformation to Industrial Revolution: The Making of Modern English Society, vol. 1, 1530-1780, New York: Pantheon Books.

Hill, C. (1980), ‘A Bourgeois Revolution?', in J.G.A. Pocock (ed.), Three British Revolutions: 1641, 1688, 1776, Princeton: Princeton University Press, pp. 109-139.

Hindle, S. (2000), The State and Social Change in Early Modern England, 1550-1640, Basingstoke: Palgrave.

Hindle, S. (2004), On the Parish? The Micro-Politics of Poor Relief in Rural England, c. 1550-1750, New York: Clarendon Press.

Hodgson, G. M. (2017), '1688 and All That: Property Rights, the Glorious Revolution and the Rise of British Capitalism', Journal of Institutional Economics, 13(1): 79-107.

Jones, N. (1989), God and the Moneylenders: Usury and Law in Early Modern England, Oxford: Basil Blackwell.

Jones, N. (1992), 'William Cecil and the Making of Economic Policy in the 1560s and Early 1570s', in P. Fidler and T.F. Mayer (eds.), Political Thought and the Tudor Commonwealth: Deep Structure, Discourse and Disguise, London: Routledge, pp. 173-198.

Jones, W. R. D. (2000), The Tree of Commonwealth, 1450-1793, Cranbury, NJ: Associated University Press.

Jones, N. (2011), 'Governing Elizabethan England', in S. Doran, and N. Jones (eds.), The Elizabethan World, London: Routledge, pp. 19-34.

Keirn, T. (1992), 'Parliament, Legislation and the Regulation of English Textile Industries, 1689-1714', in L. Davison (ed.), Stilling the Grumbling Hive: The Response to Social and Economic Problems in England, 1689-1750, Stroud: Alan Sutton, pp. 1-24.

Lipson, E. (1921), The History of the Woollen and Worsted Industries, London: A\&C Black.

Lipson, E. (1931), The Economic History of England, vol. 3, London: A\&C Black.

May, J. (1613), A Declaration of the Estate of Clothing Now Used Within This Realme of England, London: Adam Islip.

McRae, A. (1996), God Speed the Plough: The Representation of Agrarian England, 1500-1660, Cambridge: Cambridge University Press.

Misselden, E. (1622), Free Trade: Or the Meanes to Makes Trade Flourish, London: John Legatt.

Muldrew, C. (2012), “Theancient Distaff” and "Whirling Spindle": Measuring the Contribution of Spinning to Household Earnings and the National Economic in England, 1550-1770', Economic History Review, 65(2): 498-526.

Muldrew, C. (2013), 'From Commonwealth to Public Opulence: The Redefinition of Wealth and Government in Early Modern Britain', in S. Hindle, A. Shepard, and J. Walter (eds.), Remaking English Society: Social Relations and Social Change in Early Modern England, Woodbridge: Boydell Press, pp. 317-340.

Murrell, P. (2017), 'Design and Evolution in Institutional Development: The Insignificance of the English Bill of Rights', Journal of Comparative Economics, 45(1): 36-55.

Nicholas, E. (1766), Proceedings and Debates of the House of Commons in 1620 and 1621, vol. 2, Oxford: Clarendon Press.

North, D. C. and B. R. Weingast (1989), 'Constitutions and Commitment: The Evolution of Institutions Governing Public Choice in Seventeenth-Century England', Journal of Economic History, 49(4): 803-832.

North, D. C., J. Wallis and B. R. Weingast (2009), Violence and Social Orders: A Conceptual Framework for Interpreting Recorded Human History, Cambridge: Cambridge University Press.

Notestein, W., F.H. Relf, and H. Simpson (eds.) (1935), Commons Debates, 1621, vol. 7, New Haven: Yale University Press. Ogilvie, S. (2019), The European Guilds: An Economic Analysis, Princeton: Princeton University Press.

Ogilvie, S. and A.W. Carus (2014), 'Institutions and Economic Growth in Historical Perspective', in P. Aghion and S. Duelauf (eds.), Handbook of Economic Growth, vol. 2, Amsterdam: Elsevier, pp. 403-513.

Pennington, D. (2006), 'Beyond the Moral Economy: Economic Change, Ideology and the 1621 House of Commons', Parliamentary History, 25(2): 214-231. 
Perkins, H. (1969), The Origins of Modern English Society, New York: Routledge.

Pilgrim, J. E. (1959), 'The Rise of the "New Draperies” in Essex', University of Birmingham Historical Journal, 7(1): 36-59.

Pincus, S. and J. Robinson (2014), 'What Really Happened During the Glorious Revolution', in S. Galiani and I. Sened (eds.), Institutions, Property Rights and Growth: The Legacy of Douglass North, New York: Cambridge University Press, pp. 192222.

Ponting, K. (1971), The Woollen Industry of South-West England, New York: Augustus Kelley.

Ramsay, G. D. (1942), 'The Report of the Royal Commission on the Clothing Industry, 1640', English Historical Review, 57 (228): 482-493.

Ramsay, G. D. (1946), 'Industrial Laisser-Faire and the Policy of Cromwell', Economic History Review, 16(2): 93-110.

Ramsay, G. D. (1965), The Wiltshire Woolen Industry, in the Sixteenth and Seventeenth Centuries, Oxford: Oxford University Press.

Sharpe, J. (1995), 'Social Strain and Social Dislocation, 1585-1603', in J. Guy (ed.), The Reign of Elizabeth I, Court and Culture in the Last Decade, Cambridge: Cambridge University Press, pp. 192-211.

Sixta, E. F. (1953), 'Stuart Paternalism and the Manufacture of New Drapery in Colchester and Norwich, 1603-1640', PhD Thesis, University of Iowa.

Slack, P. (1990), The English Poor Law, 1531-1782, London: Macmillan.

Slack, P. (2015), The Invention of Improvement: Information and Material Progress in Seventeenth-Century England, Oxford: Oxford University Press.

Slack, P. (2017), 'The politics of English political economy in the 1620s', in Braddick M. and P. Withington (eds.), Popular Culture and Political Agency in Early Modern England and Ireland: Essays in Honour of John Walter, Woodbridge: Boydell Press, pp. 55-72.

Steele, R. (1910), Tudor and Stuart Proclamations, 1485-1714, vol. 1, Oxford: Clarendon.

Stephens, W. B. (1958), Seventeenth-Century Exeter, aStudy of Industrial and Commercial Development, 1625-1688, Exeter: A. Wheaton \& Co.

Stone, L. (1980), 'The Results of the English Revolutions of the Seventeenth Century', in J.G.A. Pocock (ed.), Three British Revolutions: 1641, 1688, 1776, Princeton: Princeton University Press, pp. 23-108.

Supple, B. (1959), Commercial Crisis and Change in England, 1600-1642, Cambridge: Cambridge University Press.

Tawney, R. H. and E. Power (eds.) (1924), Tudor Economic Documents, vol. 3, London: Longmans, Green and Co.

Thirsk, J. (1978), Economic Policy and Projects: The Development of a Consumer Society in Early Modern England, Oxford: Clarendon Press.

Thirsk, J. and J. P. Cooper (eds.) (1972), Seventeenth-Century Economic Documents, Oxford: Clarendon Press.

Wiener, C. Z. (1971), 'The Beleaguered Isle. A Study of Elizabethan and Early Jacobean Anti-Catholicism', Past \& Present, 51 (1): 27-62.

Wilson, C. (1965), England's Apprenticeship, 1603-1763, New York: St. Martin's Press.

Wrightson, K. (1980), 'Two Concepts of Order: Justices, Constables and Jurymen in Seventeenth-Century England', in J. Brewer, and J. Styles (eds.), An Ungovernable People: The English and Their law in the Seventeenth and Eighteenth Centuries, London: Hutchinson \& Co., pp. 21-46.

Wrightson, K. (2000), Earthly Necessities: Economic Lives in Early Modern Britain, New Haven: Yale University Press. Zell, M. (2001), 'Walter Morrell and the New Draperies Project, c. 1603-1631', Historical Journal, 44(2): 651-675.

Cite this article: Gendron JH (2021). Employment preservation and textile regulation in early modern England, 1550-1640. Journal of Institutional Economics 17, 529-543. https://doi.org/10.1017/S1744137421000187 